\title{
Role Play in Video to Accelerate Non-English Students' Mastery of Speaking Competence
}

\author{
Asna Usman Dilo ${ }^{(1)}, \mathbf{L a} \mathbf{A b a}^{(2)}$ \\ asnadilo77@gmail.com $^{(\mathbf{1})}$, la.aba001@ gmail.com ${ }^{(2)}$
}

IAIN Sultan Amai Gorontalo

\begin{abstract}
To teach English to non-English major students in Islamic University is unique. This perception is also applied among lecturers and to stimulate a conversation situation in which students might find and give them an opportunity to practice and develop their speaking ability. Therefore, the use of role play that involved in short film documenter or video is used in this study to make their English creatively, not only to practice speaking ability but the students can explore their acting. This study is an action research study, where pre-test and posttest are administered to obtain the data, in addition to observation and literature study. This research is carried out in two cycles, every cycle there are four components they are: planning, acting, observing, and reflecting. The result of this research showed that used role play in video can accelerate the nonEnglish students' department mastery of speaking competence. It showed the first cycle showed that only 10 or $40 \%$ students were competent. While in the second cycle, there were 25 or $88 \%$ students gained the score more than 80 . It means that the indicator of success has reached.
\end{abstract}

Keyword: Role Play in Video, Speaking Competence, Non-English Students

\begin{abstract}
Abstrak
Mengajarkan bahasa Inggris pada mahasiswa non jurusan Bahasa Inggris di perguruan tinggi Islam adalah unik. Pemahaman ini juga diterapkan pada semua dosen dan untuk merangsang situasi percakapan dimana mahasiswa menemukan dan memberikan mereka kesempatan untuk melatih dan mengembangkan kemampuan berbicara. Karena itu, penggunaan bermain peran yang dibuat dalam film pendek atau video yang digunakan dalam penelitian ini adalah untuk membuat bahasa Inggris lebih kreatif. Tidak hanya melatih kemampuan berbicara tetapi mahasiswa dan menggali kemampuan akting. Penelitian ini adalah penelitian tindakan kelas, untuk memperoleh data digunakan pre-test dan post- test, ditambah observasi dan studi literature. Penelitian ini dibuat dua siklus. Setiap siklus terdiri empat komponen : perencanaan, pelaksanaan, observasi, refleksi. Hasil dari penelitian ini menunjukkan bahwa penggunaan bermain peran yang di videokan dapat mempercepat penguasaan berbicara bagi mahasiswa non bahasa Inggris. Ini ditunjukkan pada siklus pertama hanya 10 orang atau $40 \%$ yang menguasai. Sedangkan pada siklus kedua terdapat 25 atau $88 \%$ mahasiswa memperoleh skor lebih dari 80. Menunjukkan indikator kesuksesan tercapai.
\end{abstract}

Kata Kunci: Bermain Peran, Video, Koterampilan Berbicara, Mahasiswa Non Bahasa Inggris 
Al-Lisan. Journal Bahasa \& Pengajarannya

ISSN 2442-8965 \& E ISSN 2442-8973

Volume 4 Nomor 1- Februari 2019

http://journal.iaingorontalo.ac.id/index.php/al

\section{A. INTRODUCTION}

English language is the international language or global language, spoken approximately thousand of millions of people around the world as a tool of communication. English language as a second or foreign language it is difficult for the students to learn at the first time, because it might influenced by many factors one of them might be their mother tongue to reach a successful English learner. One of the main important keys to success in English is enhanced the students come to love the learning process.

Students are able to communicate in English by mastering the four English skills such as listening, reading, writing and speaking. However, it is not easy to master all the skills; there must be one important skill that covers the whole skills. Based on the statement above speaking or oral communication is the most important skill that should be mastered by students in order to communicate in English fluently.

In this case, the students must study hard to master it and the teacher should create a good atmosphere in class. However, it is contrary to the real situation in class. Speaking activities do not work in class because many factors prevent students from speaking English with their friends. They are afraid of making mistakes, of being laughed at by his or her friends and of having lack of confidence in their ability.

There are some problems related to speaking activities in class and helping students to improve their speaking skill is part of the teacher's job. Lecturers are expected to have right teaching techniques to accelerate their English mastery with appropriate teaching materials and to create a positive classroom environment. Therefore, the students will have opportunity to use English among themselves. The teaching curriculum and learning process should not only take place between lecturers and students but also between students and students.

One of the earliest definitions of role play is provided by Mann (in Purwanto, 2008:2) where a person is asked to perform a role which is not normally his own, or is explicitly asked to perform a normal role but not in a setting where is it normally taken. Larsen and Freeman (2000:135) said that role plays are very important in communicative Language Teaching (CTL) because they give student an opportunity to practice communicating in different social contexts and different social role, similarly to Johnson and Morrow (1986:137) also said that role plays are very important in the 
Al-Lisan. Journal Bahasa \& Pengajarannya

ISSN 2442-8965 \& E ISSN 2442-8973

Volume 4 Nomor 1- Februari 2019

http://journal.iaingorontalo.ac.id/index.php/al

communicative approach therefore they give the students an opportunity to practice communicating in different social contexts. Johnson and Morrow (1987:126) said that among classroom activities, role play and simulations rate highly suitable vehicles to use in a communicative approach to language teaching. They can reduce the artificiality of the classroom, provide a reason for talking and allow the learner to talk meaningfully to other learner. According to Topkins (2008: 1) role playing is an extremely valuable method for learning. It encourage thinking and creativity, lets students develop and practice new language and behavioral skills in a relatively no threatening setting, and can create the motivation and involvement necessary for learning to occur". Similarity Livingstone (1983:6) said that role play is a classroom activity which gives students the opportunity to practice the language, the aspects of role behavior, and the actual roles he may need outside the classroom. Most students will not need to fulfill in the foreign language the wide range of roles they fulfill in the mother tongue, unless, of course, they intend to live and work in the foreign language environment for an extended period of time.

Further, Amto and several experts agreed that role play has high appeal for students because it allows them to be creative and to put themselves in another person's place for a while (Amto 2003). The explanations above indicate that role play is perhaps the liveliest form to get the class involved in speaking. Role play brings situation from real life into the classroom. Students imagine and assume roles they create a pretend situation, and they pretend to be some different persons, the following researcher would like to explain about successful classroom and speaking assessment.

Role play in video means that the students record what they are talking and have done based on the script. In the classroom the students learn through study of complex, real word practices that are captured and represented through digital video media. Implication for the design of video based environments and activities for classroom learning and lectures professional development are also addressed. Role play and video are as type of teaching media.

In regard to this media topic, Hamalik (2011) that divide classifications of teaching media into four types are: (1) Visual media, such as filmstrip, transparency, micro projection, bulletin board, pictures, illustration, chart, graphic, poster, map, and globe; (2) Audited media, such as phonograph record, electric transcript, radio, recorder 
Al-Lisan. Journal Bahasa \& Pengajarannya

ISSN 2442-8965 \& E ISSN 2442-8973

Volume 4 Nomor 1- Februari 2019

http://journal.iaingorontalo.ac.id/index.php/al

of tape recorder; (3) Audio visual media, such as film, TV, and three dimensions things; and (4) Dramatization, role play, socio drama, etc

The use of video is suggested as a learning medium. There are many reasons why the use of video is suggested as a learning medium. As suggested by Harmer (2004: 282) stated that some of the reasons as to why the language teacher is advised to use video as a medium of learning and teaching, are: (1) Language learners not only hear the language they learn, but they also look at the context directly from the video being played. Video will be a marvelous medium that represents expressions, gestures and other visual forms; (2) The knowledge of cultural differences. Video will enable students to see situations outside the classroom without having to leave the classroom; (3) Learning material in the media would be easy to remember because it is fun; and (4) The video can enhance students' motivation and interest in learning. It is as described previously that students not only learn how to see, but also listen, and it will be interesting for them so their motivation to learn will also increase.

\section{B. RESEARCH METHOD}

The research takes place at in Economic and Islamic Business Faculty at IAIN Sultan Amai Gorontalo. The subject of this study is the third semester of Islamic Banking department with 33 students. This study is a classroom action research (CAR) as it serves the purpose of the study to accelerate the mastery of non-English students' of speaking competence. It will conduct for six weeks, starting from the first week of October 2018 up to the third week of November 2018.

In this study the data are collected applying role play in video. Research findings describe which are gathered from the conduct of this action research. Data is the process implementation of role playing process based on the observation. The second data is students' speaking competence, which is gained from the observation to the students when the role playing applied in the dialogues.

The research is conducted in two cycles, where each cycle consists of 6 meetings. Research subjects are divided into 6 (six) groups then prepare dialogue or script of the text based on the theme Islamic banking activities. At end of each cycle, lecturers' achievement is measured using collected through a rubric of fluency as a general term of oral language proficiency. So the main point to access students' ability by using language proficiency as one of the analytic rating scales. The rubric was used to assess 
Al-Lisan. Journal Bahasa \& Pengajarannya

ISSN 2442-8965 \& E ISSN 2442-8973

Volume 4 Nomor 1- Februari 2019

http://journal.iaingorontalo.ac.id/index.php/al

or evaluate the students' speaking ability. Schmidt (1992) believes that fluency is processing power in really using the language. Skehan in Richard (2003) also emphasizes speaking that fluency cannot be separated from the meaning of the language, for it reflects learners' ability to deal with real communication in different contexts can be seen in table 1 below.

Table 1. The Features and Description of Language Proficiency

\begin{tabular}{|l|l|}
\hline \multicolumn{1}{|c|}{ Features } & \multicolumn{1}{|c|}{ Description } \\
\hline Pronunciation & $\begin{array}{l}\text { Pronunciation of individual sounds and words, } \\
\text { stress }\end{array}$ \\
\hline Grammar & $\begin{array}{l}\text { Language use: accurate use of structure,or how } \\
\text { the learners get his/ her utterances correct }\end{array}$ \\
\hline Vocabulary & $\begin{array}{l}\text { The learner's ability in choosing appropriate } \\
\text { words for the intended meaning, and how to } \\
\text { solve the problems when he/she connot find } \\
\text { suitable words }\end{array}$ \\
\hline Fluency & $\begin{array}{l}\text { The ability to keep the expression going } \\
\text { smoothly, e.g. read a text without hesitation/ in } \\
\text { appropriate pauses, or without repeating the } \\
\text { words/line }\end{array}$ \\
\hline Confidence & $\begin{array}{l}\text { The ability to get the meaning across to the } \\
\text { listener. }\end{array}$ \\
\hline intonation to show feeling.
\end{tabular}

In collecting the students' speaking ability in performing the learning tasks, I rated the holistic scoring on a five-point scale for each elements of fluency. They are : Excellent (5); Very good (4); Good (3); Fair (2); Poor (1).

After the students' score were analyzed based the scales and their description, I accumulated the totality of the students' scores gained in speaking assessments. Then I calculated the students' own score to get their learning result in each cycle. The result was then classified into five criteria, they were extremely competent, competent, enough 
Al-Lisan. Journal Bahasa \& Pengajarannya

ISSN 2442-8965 \& E ISSN 2442-8973

Volume 4 Nomor 1- Februari 2019

http://journal.iaingorontalo.ac.id/index.php/al

competent, incompetent, and extremely incompetent. Based on the statement, I modified the criteria of the students' learning achievement values as shown in table 2 .

Table 2. The Criteria and the Value of the Students' Learning Achievement

\begin{tabular}{|c|l|c|}
\hline NO & \multicolumn{1}{|c|}{ Criteria } & Intervals of Value \\
\hline 1. & Extremely Competent & $90-100$ \\
\hline 2. & Competent & $70-89$ \\
\hline 3. & Enough Competent & $60-69$ \\
\hline 4. & Incompetent & $40-59$ \\
\hline 5. & Extremely Incompetent & $0-39$ \\
\hline
\end{tabular}

The table above interprets that if students gain values more than 90 , they are called extremely competent students. Students who obtained values 70 to 89 , they are called competent students. When the students have values between 60 and 69, they are enough competent students. However, if they obtained the intervals of values between 40 and 59, it called categorized incompetent students. Whereas, values less than 39 , it is extremely incompetent students. It can be claimed that the students are called successful in learning if the participants have reached the score of at least 70 or they have the classification of value competent at least.

\section{FINDINGS AND DISCUSSIONS}

\section{Findings}

First Cycle

At the first meeting the students divided into six groups and choose the theme. The theme revolves around Islamic Banking activities like selling and buying, market, banking activities. And then they discuss with their group to enactive the title of dialogue, make draft script of dialogue; destine the place and who are actor in this section. Lecturers give them opportunity for three weeks to apply role play into video. Next section the students show that into the classroom with a time has decided. In each meeting, one group present their video, lecturers observed the students' ability in the presentation, therefore each student was expected to speak fluently. The result of the first cycle, a few group that the students' speaking fluency ability in this meeting shows 
Al-Lisan. Journal Bahasa \& Pengajarannya

ISSN 2442-8965 \& E ISSN 2442-8973

Volume 4 Nomor 1- Februari 2019

http://journal.iaingorontalo.ac.id/index.php/al

that some of them still less fluent when they speak, some students are nervous; not dominate the script. It became the students' learning achievement in the first cycle.

After analyzing the students' speaking fluency in the first cycle, founded that the students' speaking fluency based on the elements of speaking in the first cycle can be seen in table 3 below:

Table 3. Data of the Students' Speaking Fluency in the First Cycle based on the elements of Speaking for all groups:

\begin{tabular}{|l|l|c|}
\hline No & The Elements of Speaking & Total Score \\
\hline 1 & Fluency & 17 \\
\hline 2 & Grammar & 20 \\
\hline 3 & Pronunciation & 21 \\
\hline 4 & Comprehensibility & 23 \\
\hline 5 & Vocabulary & 23 \\
\hline 6 & Confidence & 21 \\
\hline \multicolumn{2}{|r|}{ Total } & $67,89 \%$ \\
\hline
\end{tabular}

The table above shows that in the first cycle only $67.89 \%$. This result is yet to meet the standard achievement set as the indicator of this study. It means after cycle 1 was done students' speaking fluency seemed to be increased compare to the preliminary study.

When the scores of the students' speaking ability were classified into the criteria of value, it presents in table 4 .

Table 4. Data of the Students' Speaking fluency in the First Cycle Based on the Criteria of Value

\begin{tabular}{|l|l|c|c|c|}
\hline No & \multicolumn{1}{|c|}{ Criteria } & Interval of Value & Frequency & Percentage \\
\hline 1 & Extremely Competent & $90-100$ & 0 & 0 \\
\hline 2 & Competent & $70-89$ & 6 & 18,2 \\
\hline 3 & Enough Competent & $60-69$ & 19 & 57,6 \\
\hline 4 & Incompetent & $40-59$ & 8 & 24.2 \\
\hline 5 & Extremely Incompetent & $0-39$ & 0 & 0 \\
\hline \multicolumn{2}{|c|}{ Total } & 33 & 100 \\
\hline
\end{tabular}


Al-Lisan. Journal Bahasa \& Pengajarannya

ISSN 2442-8965 \& E ISSN 2442-8973

Volume 4 Nomor 1- Februari 2019

http://journal.iaingorontalo.ac.id/index.php/al

Data in table 4 shows that no one student is classified into extremely competent criteria. There were only six students or $18,2 \%$ have competent criteria because they obtain values between 70 and 89 . Nineteen students or $57,6 \%$ are enough competent criteria because their values are between 60 and 69. Eight students or $24.2 \%$ were in incompetent criteria. It means after cycle 1 was done students' speaking fluency seemed to be increased compare to the preliminary study.

\section{Second Cycle}

In this section lecturers explain the result of video each group and what a lack of each actors, sound, backdrop of stage, their speech is not clear, errors grammatical. Lecturers give them opportunity for two weeks to record then apply again role play into video with observe all aspect. They also prepare similar materials in the script. Lectures corrected the script with identify grammatical errors. The next section they have presenting again the video.

The result of the second cycle show that the student's speech is clear, they have confidents to talk with their friends, their acting seemly natural, grammar is correct, a word corrected pronounced, the audience could understand everything student said and express, uses appropriated vocabulary, there are speaking confidently with proper intonation to show feeling. All score can be shown at table 5 below.

Table 5. Data of the Students' Speaking Fluency in the First Cycle based on the elements of Speaking for all group:

\begin{tabular}{|l|l|c|}
\hline No & The Elements of Speaking & Total Score \\
\hline 1 & Fluency & 30 \\
\hline 2 & Grammar & 30 \\
\hline 3 & Pronunciation & 31 \\
\hline 4 & Comprehensibility & 29 \\
\hline 5 & Vocabulary & 31 \\
\hline 6 & Confidence & 30 \\
\hline \multicolumn{2}{|c|}{ Total } & $86,30 \%$ \\
\hline
\end{tabular}

Based on calculating the result of the score shows that in the second cycle reach $86.30 \%$. Its means the standard achievement set as the indicator of this study. 
Al-Lisan. Journal Bahasa \& Pengajarannya

ISSN 2442-8965 \& E ISSN 2442-8973

Volume 4 Nomor 1- Februari 2019

http://journal.iaingorontalo.ac.id/index.php/al

When the scores of the students' speaking ability were classified into the criteria of value, it presents in table 6.

Table 6. Data of the Students' Speaking fluency in the First Cycle Based on the Criteria of Value

\begin{tabular}{|l|l|c|c|c|}
\hline No & \multicolumn{1}{|c|}{ Criteria } & Interval of Value & Frequency & Percentage \\
\hline 1 & Extremely Competent & $90-100$ & 0 & 0 \\
\hline 2 & Competent & $70-89$ & 12 & 27,5 \\
\hline 3 & Enough Competent & $60-69$ & 21 & 63,6 \\
\hline 4 & Incompetent & $40-59$ & 0 & 0 \\
\hline 5 & Extremely Incompetent & $0-39$ & 0 & 0 \\
\hline \multicolumn{2}{|c|}{ Total } & 33 & 100 \\
\hline
\end{tabular}

In table 6 shows that twelve students or $27,5 \%$ have competent criteria. Twenty one students or $63,6 \%$ are enough competent criteria, there no students were in incompetent criteria. Considering the value above, the indicator for the completion of this study have reached.

\section{Discussion}

As seen in the findings above, the role play in video is able to accelerate the students' speaking competence from the average of 67,9 to 86,3 at the second cycle. Like Pageyasa (2004) states that mastery of speaking theory is not main purpose in teaching speaking. The important things are students are able to speak agreeing to contexts and the teaching of speaking must be oriented to aspect of language use, not to language rules. The other hand Harmer (2007) said that "filmed extracts can be used as a main focus of a lesson sequence or as parts of other longer sequences." Students are used to watching film at home, and they enjoyed those things. As English lectures we need to be sure that we provide the students with good viewing and listening tasks so that they give their full attention to what they are seeing and hearing. By role play in video the student determine his or her own personal strengths and weaknesses. The other researcher is Zhihong Lu, etc (2010) in her study found that Audio-Video as media to teach the students in speaking. Relating to media like video, Irma Manda 
Al-Lisan. Journal Bahasa \& Pengajarannya

ISSN 2442-8965 \& E ISSN 2442-8973

Volume 4 Nomor 1- Februari 2019

http://journal.iaingorontalo.ac.id/index.php/al

(2017) make a research about the use of audio visual media in teaching English for nonEnglish majors.

The subject of these researches is having different background or composite students from senior high school and Islamic school. And it influence the result of study, in addition to make the participant easy make dialogue is a material or theme familiar with them because all subject of lesson almost talking about Islamic banking.

Lecturers need created another instrument for far- ranging advantage of using video in accelerating the English mastery of non-English students at IAIN Sultan Amai Gorontalo. In addition we should to found the other approach or media that interesting for the students to learn English lesson so they have motivate to follow the English lesson more than it to increase English mastery.

As a lesson learned, role play in video can be claimed can accelerate the students' speaking competence by using closer theme with their core of study or students department. It implies that lectures should role play in video as approach to beneficial in increasing their English language mastery. 
Al-Lisan. Journal Bahasa \& Pengajarannya

ISSN 2442-8965 \& E ISSN 2442-8973

Volume 4 Nomor 1- Februari 2019

http://journal.iaingorontalo.ac.id/index.php/al

\section{CONCLUSION}

As we go through this study, speaking fluency on one language can help us to communicate, interact and socializing with others. To speak English fluency, than there are some important parts of the languages that we have to master such as grammar, vocabulary, pronunciation, fluency and even confidence. This study has argued that role play recorded in video can be used as a technique that provide opportunities for lectures and students feedback and motivate students because of their engaging qualities. The way lectures should correct in speaking fluency activities, not interrupting while they are going on, but giving feedback later. There may be times when teachers need to help an activity along through participation provided that has to be done sensitively. 


\section{REFERENCES}

Abbas Pourhosein Gilakjani Department of English Language Translation, Lahijan Branch, Islamic Azad University, Lahijan, Iran . I.J. Modern Education and Computer Science, 2012, 4, 57-66 Published Online May 2012 in MECS (http://www.mecs-press.org/) DOI: 10.5815/ijmecs.2012.04.08.

Amiri, Mostafa., Azhar Husaini, Fatemi. (2014). The impact of content-based instruction on students' achievement in ESP courses and their language learning orientation. The Theory and Practices on Language Studies. Vol. 4 (10). Pp 2157-2167, October 2014, Retrieved April 2015 from: https://profdoc.um.ac.ir/articles/a/1044240.pdf

Amato, Patricia A. Richard, 2003, Making it Happen: from Interactive to Participatory Language Teaching, Usa: Logman

Bailey, Kathleen, 2005. Issue in Teaching Speaking Skill to Adult ESOL Learners, NSCSALL Journa.l

Byrne, Donn, 1989, Techniques for Classroom Interaction to Research Methods, Malaysia: Logman Malaysia, PA

Byrne, Donn. 1986. Teaching Oral English, London: Longman

Campbell, D., Cook, K.J., Kusch, B. \& Moulton, S. (2009). Inspiring Learning and Teaching: Using e-tools to Facilitate Change. In T. Bastiaens, J. Dron \& C. Xin (Eds.), Proceedings of E-Learn 2009--World Conference on E-Learning in Corporate, Government, Healthcare, and Higher Education (pp. 172-181). Vancouver, Canada: Association for the Advancement of Computing in Education (AACE). Retrieved January 30, 2019 from https://www.learntechlib.org/primary/p/32454

Lu, Z., Hou, L. \& Huang, X. (2010). A research on a student-centred teaching model in an ICT-based English audio-video speaking class. International Journal of Education and Development using ICT, 6(3), 101-123. Open Campus, The University of the West Indies, West Indies. Retrieved January 31, 2019 from https://www.learntechlib.org/p/42381/.

Richards, J., \& Rodgers, T. (2001). Approaches and methods in language teaching. New York: Cambridge University Press.

Richard, Jack C. 2003. Current Trends in Teaching and Listening and Speaking. Macquarie University, Sydney, Australia

Stroller, F. (2002). Project Work: A means to promote language and content. In J. C. Richards \& W. A. Renandya (eds.), Methodology in Language teaching: An antohology of current practice. Cambridge: Cambridge University Press, 107-119 